\title{
First data on the biological richness of Mediterranean springs
}

\author{
Roger Pascual ${ }^{1, *}$, Alfonso Nebra ${ }^{2}$, Joan Gomà ${ }^{3}$, César Pedrocchi ${ }^{4}$, Oda Cadiach ${ }^{1}$, Guillermo \\ García $^{1}$ and Jaume Solé ${ }^{1}$ \\ 1 Societat Catalana de Ciències per la Conservació de la Biodiversitat (Bioscicat) Rambla Nova 21, entresol 1a, \\ 43003 Tarragona. \\ 2 Centro Tecnológico del Mar-Fundación CETMAR, Eduardo Cabello s/n 36208 Bouzas-Vigo (Pontevedra). \\ 3 Dept. Biologia Evolutiva, Ecologia i Ciències ambientals. Universitat de Barcelona. Av. Diagonal 645. 08028. \\ Barcelona. \\ ${ }^{4}$ C. Sant Sebastià 1, 43887 Nulles, Tarragona. \\ * Corresponding author: rpascual@bioscicat.org
}

Received: $13 / 09 / 18$

Accepted: 01/07/19

\begin{abstract}
First data on the biological richness of Mediterranean springs

The taxonomic richness of the main biological groups in springs in the Mediterranean biogeographical region has been investigated for the first time. This work has focused on two mountainous areas of mainly limestone substrata: the Montsant massif (south of the Catalan pre-coastal ranges, NE Iberian Peninsula) and the Serra de Tramuntana (north of the island of Mallorca). The taxa of macroalgae, diatoms, bryophytes, cormophytes, aquatic invertebrates and vertebrates have been analysed in ten springs of each area, and a total of 500 taxa have been identified in Montsant (ranging between 82-152 taxa per site) and 363 taxa in Serra de Tramuntana (ranging between 55-119 taxa per site). Depending on each spring, the biological groups showing the greatest richness value are either cormophytes, diatoms or invertebrates. The resulting biological richness, which is reported for the first time in Mediterranean crenic systems, is similar to the values found in other published works on springs in the Euro-Siberian biogeographic region, showing their role as outstanding biodiversity hot spots also in Mediterranean environments. The similarity analysis showed that the springs shared a low number of taxa, resulting in a low value of similarity. In conclusion, the results suggested that each spring could represent a unique, unrepeatable community.
\end{abstract}

Key words: freshwater springs, biological richness, crenocenosis, Mediterranean bioregion, Montsant, Serra de Tramuntana

\section{RESUMEN}

\section{Primeros datos sobre la riqueza biológica de las fuentes mediterráneas}

Se investiga por primera vez la estructura biocenótica y la riqueza taxonómica asociada a los hábitats fontanales de la región biogeográfica mediterránea, tanto en ecosistemas continentales como insulares, a través del inventariado de sus principales grupos biológicos. El trabajo se ha centrado en dos áreas montañosas de naturaleza calcárea: el macizo de Montsant (sur de las sierras prelitorales catalanas) y la Serra de Tramuntana (norte de la isla de Mallorca). Se ha analizado sistemáticamente los taxones de macroalgas, diatomeas, briófitos, cormófitos, invertebrados acuáticos y vertebrados en 10 fuentes de cada región, y se ha identificado un total de 500 taxones en Montsant (con un rango de 82-152 taxones por fuente) y de 363 taxones en la Serra de Tramuntana (con un rango de 55-119 taxones por fuente). Dependiendo de cada fuente, los grupos biológicos que exhiben mayor riqueza son los cormófitos, las diatomeas o los invertebrados. La riqueza biológica hallada y que reportamos por primera vez para ecosistemas fontanales mediterráneos, es similar a la encontrada por otros autores en fuentes de la región biogeográfica eurosiberiana y demuestra su papel como focos excepcionales de biodiversidad también en ambientes mediterráneos. El análisis de similitud muestra que las fuentes presentan una baja proporción de taxones coincidentes entre ellas, lo que resulta en un valor bajo de similitud. En consecuencia, los resultados sugieren que cada fuente podría conformar en si misma una comunidad única e irrepetible.

Palabras clave: fuentes, riqueza biológica, crenocenosis, biorregión mediterránea, Montsant, Serra de Tramuntana 


\section{INTRODUCTION}

Natural springs are the result of the upwelling of underground water on the earth's surface (Van der Kamp, 1995). As aquifers are often large and are found relatively isolated from atmospheric factors, the springs they nourish usually show a proverbial stability in their flow and the physico-chemical characteristics of the water, in contrast with other freshwater ecosystems (Thienemann, 1922; Odum, 1971; Margalef, 1983). Moreover, springs are transitional ecosystems constituting ecoclines among subterranean and fluvial aquatic ecosystems (Williams, 1991) and also forming ecotones between the first and terrestrial ecosystems (Gibert et al., 1991). This transitional nature causes springs to present a great variety of microhabitats in a relatively small area, which is deciphered as high levels of biological richness (Cantonati et al., 2006; Cantonati et al., 2012a; Reiss, 2013; Reiss \& Chifflard, 2015). Springs also play a fundamental role in the ecology of both intermittent and temporary streams in the Mediterranean basin by acting as a reservoir and a source of the species that will colonise them during the months of greatest flow (Thorp \& Covich, 2015).

In spite of their ecological relevance, these unique ecosystems barely attracted the attention of ecologists and limnologists until 1990s. This was when a series of studies focusing on the analysis of several biological groups present in the springs began, mainly in Europe, North America and Australia (e.g. Sabater \& Roca, 1992; Webb et al., 1995; Aboal et al., 1998; Hatton \& Evans, 1998). The biological groups most frequently studied were diatoms or aquatic invertebrates, mainly because of the relatively deep knowledge of their taxonomy and ecological requirements which has allowed their use as bioindicators in monitoring programs (Lai et al., 2016; Rosati, 2016).

All this shows the ecological importance of springs, particularly considering that they constitute important hot spots of biodiversity in a small area of occupancy (Botosaneanu, 1995; Scarsbrook et al., 2007; Cantonati et al., 2012a). However, full biota studies associated with crenocenosis (at least regarding the most relevant taxonomic groups) have been practically non-existent. Only the work of Cantonati \& Ortler (1998), in which 30 springs located in the montane and Alpine stages from the south-eastern Alps were sampled and a total of 730 taxa were identified, is worth mentioning. The unusual taxonomic richness of the spring environments has been linked to their transitional nature: their organisation in an intricate mosaic of microhabitats, offering a gathering of crenophilous and crenobiont organisms (which live mostly or only in springs, respectively), styghophilous and stygobiont organisms (which develop mostly or only in underground water bodies, respectively), rheophilous organisms (those living in flowing waters), limnophilous organisms (which inhabit stagnant lenitic waters), as well as species typical of water films on rocky or other kinds of substrates (hygropetric and liminaria) and terrestrial taxa adapted to wet and moist substrata (Gerecke et al., 1998; Reiss, 2013; Reiss \& Chifflard, 2015).

In the Mediterranean biogeographic region, as in the rest of arid and semiarid bioclimates of the Earth, springs are often the only permanent freshwater systems in large areas and they are therefore crucially important for the survival of some organisms (Stevens \& Meretsky, 2008). Research focused on the biodiversity associated with the Mediterranean spring ecosystems is scarce, with few studies of certain biological groups having been reported up to now: diatoms (Aboal et al., 1998; Delgado et al., 2013: Lai et al., 2016), bryophytes (Bes et al., 2017), water mites (Di Sabatino et al., 2003) and copepods (Fiasca et al., 2014).

Although these works reported high biodiversity levels, Mediterranean springs have surprisingly not been subject to systematic studies considering the main biological groups that inhabit them in an integrated way. In order to offset this lack of basic knowledge of our natural systems, the aim of the present study has focused on: 1) obtaining a first approach to the taxonomic richness of Mediterranean spring ecosystems (both continental and insular), and particularly of their most representative biological groups, and 2) assessing to what extent the biotic communities from the different studied springs are connected. Both are essential not only to discover the biological richness that depends on crenic habitats, but 


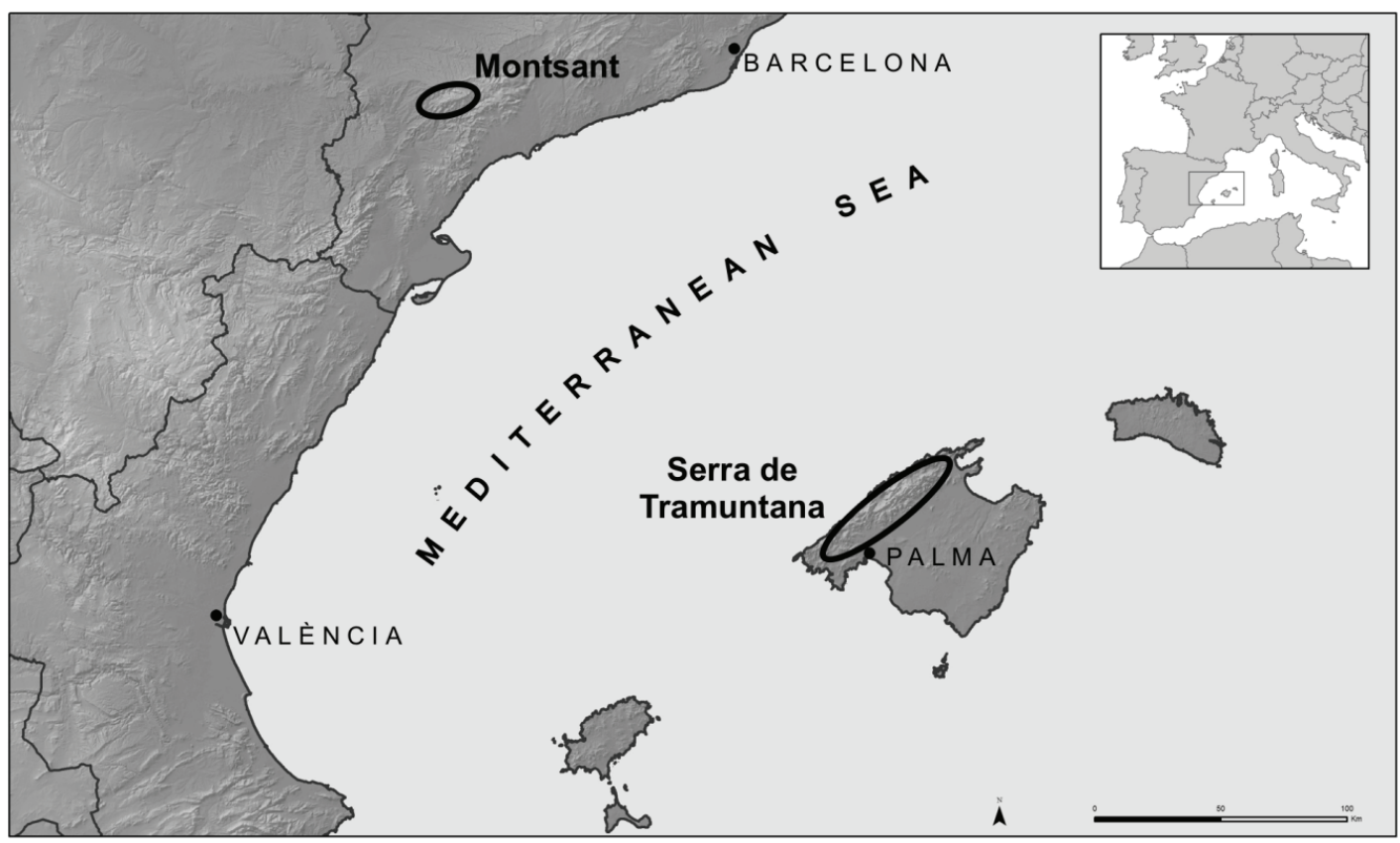

Figure 1. Location of the western Mediterranean mountainous areas where the spring biodiversity sampling has been performed. Situación de las áreas montañosas del Mediterráneo occidental donde se ha realizado el muestreo de biodiversidad de las fuentes.

also to understand whether the spring network in mountain ranges with ephemeral or temporary streams could increase the ecological resilience of other inland freshwater habitats.

\section{MATERIALS AND METHODS}

\section{Study areas}

This study was carried out at a total of 20 springs, half of them located in the Montsant massif (a region of Priorat in the south of Catalonia) and the other half in Serra de Tramuntana (northwest of Mallorca), both natural areas with special protection (Natural Park in Montsant and Natural Site in Serra de Tramuntana, Fig. 1). All the springs selected have continuous discharge, even during the summer drought period. The location and geological features of the springs studied are displayed in Tables 1 and 2. Both mountain ranges are mainly characterised by permeable carbonaceous materials. Conglomerates are predominant in Montsant and limestones and dolomites are prevalent in Serra de Tramuntana.
Both areas are in the Mediterranean climatic region, pluviseasonal oceanic variant, with a thermal regime that turns from the mesomediterranean at low and medium levels to supramediterranean in higher areas (Rivas-Martínez \& Rivas-Sáenz 1996-2009), reaching a maximum altitude of $1163 \mathrm{~m}$ in Montsant and $1436 \mathrm{~m}$ in Serra de Tramuntana. Nevertheless, both areas show significant differences in relation to their microclimatic characteristics. On one hand, in Montsant, the climate in the lowlands shows a clear continental tendency, with cold winters (5-7 ${ }^{\circ} \mathrm{C}$ ), high annual thermal amplitude of $17-20{ }^{\circ} \mathrm{C}$ and a rainfall system with two peaks (autumn and spring) and a winter minimum in February, in addition to the summer minimum (Ninyerola et $a l ., 2001)$. On the other hand, in Serra de Tramuntana, maritime influence are much stronger, favouring temperate winters $\left(10-12^{\circ} \mathrm{C}\right)$, lower thermal amplitude $\left(13-15^{\circ} \mathrm{C}\right)$ and a rain regime with just one maximum in autumn, while the winter minimum is non-existent or very small (Guijarro, 1986). It is also worth mentioning that the average annual rainfall totals $450-700 \mathrm{~mm}$ in 
Table 1. List of the springs of the Montsant sampled in this study, with the detail of the local geology. The location is provided in geographic coordinates with ETRS89 datum. ID: identifier; h: topographic altitude (m a.s.1.). Relación de las fuentes de Montsant objeto de estudio, con el detalle de la geología local. La ubicación se proporciona en coordenadas geográficas con datum ETRS89. ID: identificador; $h$ : altitud topográfica $(m)$.

\begin{tabular}{|c|c|c|c|c|c|c|c|}
\hline \multirow{2}{*}{ ID } & \multirow{2}{*}{ Spring name } & \multicolumn{2}{|c|}{ Coordinates $\left({ }^{\circ}\right)$} & \multirow{2}{*}{$\mathrm{h}$} & \multirow{2}{*}{ Era } & \multirow{2}{*}{ Period / Epoch } & \multirow{2}{*}{ Main lithology } \\
\hline & & Lon. & Lat. & & & & \\
\hline M01 & Font de Cavaloca & 0.76037 & 41.25560 & 579 & Cenozoic & Eocene & $\begin{array}{l}\text { Yellow lutites, sandstones and } \\
\text { conglomerates }\end{array}$ \\
\hline M12 & Font del Barranc & 0.72569 & 41.22556 & 291 & Mesozoic & $\begin{array}{l}\text { Middle Triassic } \\
\text { (Muschelkalk) }\end{array}$ & $\begin{array}{l}\text { Fine grain sandstones and red clay, } \\
\text { with gypsum levels }\end{array}$ \\
\hline M15 & $\begin{array}{l}\text { Degotall del Clot } \\
\text { del Cirer }\end{array}$ & 0.81858 & 41.28068 & 993 & Cenozoic & Eocene / Oligocene & $\begin{array}{l}\text { Limestone, conglomerates, sandstones } \\
\text { and red and ochre marls }\end{array}$ \\
\hline M19 & $\begin{array}{l}\text { Font del Mas de } \\
\text { Sant Blai }\end{array}$ & 0.85577 & 41.26178 & 547 & Paleozoic & Carboniferous & $\begin{array}{l}\text { Fine grain sandstones, slates, phyllites, } \\
\text { andesites and conglomerates }\end{array}$ \\
\hline M20 & $\begin{array}{l}\text { Font del Mas del } \\
\text { Soleràs }\end{array}$ & 0.80638 & 41.30341 & 457 & Cenozoic & Eocene / Oligocene & $\begin{array}{l}\text { Limestone, conglomerates, sandstones } \\
\text { and red and ochre marls }\end{array}$ \\
\hline M23 & Font Pregona & 0.81465 & 41.26709 & 645 & Cenozoic & Eocene / Oligocene & $\begin{array}{l}\text { Limestone, conglomerates, sandstones } \\
\text { and red and ochre marls }\end{array}$ \\
\hline M26 & Font de les Planes & 0.74619 & 41.22265 & 200 & Cenozoic & Quaternary & Cobbles, gravels and sands \\
\hline M27 & La Fonteta & 0.76654 & 41.22304 & 211 & Cenozoic & Quaternary & Cobbles, gravels and sands \\
\hline M35 & Font de la Gleva & 0.84483 & 41.31496 & 545 & Cenozoic & Eocene & $\begin{array}{l}\text { Yellow lutites, sandstones and } \\
\text { conglomerates }\end{array}$ \\
\hline M38 & Font del Peret & 0.87881 & 41.30335 & 750 & Cenozoic & Eocene & $\begin{array}{l}\text { Yellow lutites, sandstones and } \\
\text { conglomerates }\end{array}$ \\
\hline
\end{tabular}

Montsant, while in Serra de Tramuntana it rises from $500 \mathrm{~mm}$ approximately in the south-eastern basal area to $1400 \mathrm{~mm}$ at the highest altitudes.

\section{Spring sampling}

In this study, a total of 20 springs were sampled. The surveys for the examination of the spring ecosystems in Montsant were developed during the summer of 2015 (from 23 June to 5 August), while the samples from the springs in Serra de Tramuntana were obtained during late summer of 2017 (from 4 to 7 September). The sampling routine formerly consisted of delimiting the springs' area of influence and measuring the flow and the main water physico-chemical features: temperature, conductivity, dissolved solids, $\mathrm{pH}$, and dissolved oxygen, using a multiparameter probe: EUTECH PCD650. The physico-chemical characterisation of each spring preceded the sampling of the different biological groups on which the study is focused. The sampling procedure was organised in the following order: begin- ning with cormophytes and bryophytes, followed by vertebrates, macroalgae, diatoms and, finally, macroinvertebrates and microcrustaceans.

Sampling of cormophytes. This consisted of the identification of the taxa in the spring environment at the specific level, according to Bolòs \& Vigo keys (1984-2001). Only samples of the plants which could not be identified directly in the field were botanised for further accurate examination. The sampling effort was that strictly necessary to identify all the possible different taxa in the area influenced by the spring.

Sampling of bryophytes. Both submerged habitats and peripheral wet substrates and carbonate precipitates (wet or dry) were examined. Samples of the various mosses or liverworts distinguishable at first sight in each one of the environments were extracted, paying attention to possible microspecies among the dominant ones, while the amount of each specimen collected was the minimum necessary for its correct identification. The excess water was removed from the samples in the field, which were subsequently 
preserved in paper envelopes labelled with the corresponding code until further analysis. The sampling lasted until no new taxa were found. The taxa determination was performed in the laboratory, with the general review of the sample, the selection of specimens under binocular magnifying glass and the observation of phyllids and cross sections of phyllids and stems as well as other microscopic structures under the optical microscope. The keys of the bryophyte floras that cover the studied areas were Casas et al. (2004, 2006) and Guerra et al. (2006, 2010, 2014).

Sampling of macroalgae. The different microhabitats were thoroughly examined and samples of algae perceptible at plain sight were picked up. They were introduced in $5 \mathrm{ml}$ tubes in which 4.5 $\mathrm{ml}$ of water from the environment was added. In the case of Charophyceae, $100 \mathrm{ml}$ plastic bottles filled with water from the environment were used. After adding the required volume of concentrated formaldehyde (38-40\%) to obtain a final concentration of $\approx 1 \%$, samples were kept at $4{ }^{\circ} \mathrm{C}$ until their analysis. They were examined in the laboratory with the optical microscope, identifying the macroalgae taxa with the highest possible resolution. Several bibliographical sources were used to identify them (John et al., 2005; Cirujano et al., 2007; Komárek \& Anagnostidis, 2008; Bellinger \& Sigee, 2010). Some of the taxa - particularly from Zygnematales, Oedogoniales and Oscillatoriales - could not be specifically identified because they did not show reproductive structures. In this case, the specimens were classified in morphotypes according to their cellular features.

Sampling of diatoms. Whenever possible, the

Table 2. List of the springs of the Serra de Tramuntana sampled in this study, with the detail of the local geology. The location is provided in geographic coordinates with ETRS89 datum. ID: identifier; h: topographic altitude (m a.s.1.). * Coordinates for these springs correspond to the sampled environment at the discharge point, since the original upwelling is completely piped. Relación de las fuentes de la Serra de Tramuntana objeto de estudio, con el detalle de la geología local. La ubicación se proporciona en coordenadas geográficas con datum ETRS89. ID: identificador; h: altitud topográfica $(m)$. * En estas fuentes se dan las coordenadas del ambiente muestreado en el punto de emergencia del agua, puesto que la surgencia original está entubada completamente.

\begin{tabular}{|c|c|c|c|c|c|c|c|}
\hline \multirow{2}{*}{ ID } & \multirow{2}{*}{ Spring name } & \multicolumn{2}{|c|}{ Coordinates $\left({ }^{\circ}\right)$} & \multirow{2}{*}{$\mathrm{h}$} & \multirow{2}{*}{ Era } & \multirow{2}{*}{ Period / Epoch } & \multirow{2}{*}{ Main lithology } \\
\hline & & Lon. & Lat. & & & & \\
\hline T01 & Font de sa Menta & 2.49772 & 39.67196 & 189 & Cenozoic & Holocene & Gravels and boulders \\
\hline T02 & Font des Albellons* & 2.90954 & 39.83842 & 617 & Mesozoic & Jurassic (Lias) & $\begin{array}{l}\text { Limestones, dolomites and } \\
\text { breccia }\end{array}$ \\
\hline T03 & Font des Puig Ferrer & 2.89720 & 39.81740 & 542 & Mesozoic & $\begin{array}{l}\text { Upper Triassic } \\
\text { (Keuper/Rhaetian) }\end{array}$ & $\begin{array}{l}\text { Lutites, sandstones, gypsum and } \\
\text { volcanic rocks / Dolomites, dolomitic } \\
\text { breccia and cellular dolomites }\end{array}$ \\
\hline T06 & Font de s'Olla & 2.71146 & 39.75700 & 77 & Mesozoic & $\begin{array}{l}\text { Upper Triassic } \\
\text { (Rhaetian) }\end{array}$ & $\begin{array}{l}\text { Dolomites, dolomitic breccia and } \\
\text { cellular dolomites }\end{array}$ \\
\hline T08 & Font des Pi & 2.80737 & 39.77131 & 470 & Mesozoic & Jurassic (Lias) & $\begin{array}{l}\text { Limestones, dolomites, marls, } \\
\text { sandstones and chalcodolomitic } \\
\text { breccia in the base }\end{array}$ \\
\hline T09 & Font de Muntanya & 2.92210 & 39.85003 & 521 & Mesozoic & $\begin{array}{l}\text { Upper Triassic } \\
\text { (Rhaetian) }\end{array}$ & $\begin{array}{l}\text { Dolomites, dolomitic breccia and } \\
\text { cellular dolomites }\end{array}$ \\
\hline $\mathrm{T} 10$ & Font des Molinet* & 2.94875 & 39.85833 & 159 & Mesozoic & $\begin{array}{l}\text { Upper Triassic } \\
\text { (Keuper) }\end{array}$ & $\begin{array}{l}\text { Lutites, sandstones, gypsum and } \\
\text { volcanic rocks }\end{array}$ \\
\hline $\mathrm{T} 11$ & Font de l'Assarell* & 2.97641 & 39.84693 & 433 & Cenozoic & $\begin{array}{l}\text { Middle Miocene } \\
\text { (Langhian) }\end{array}$ & Marls, siltstones and sandstones \\
\hline $\mathrm{T} 12$ & $\begin{array}{l}\text { Font de son Tries de } \\
\text { Dalt }\end{array}$ & 2.57148 & 39.66461 & 293 & Mesozoic & Jurassic (Lias) & $\begin{array}{l}\text { Limestones, dolomites, marls, } \\
\text { sandstones and chalcodolomitic } \\
\text { breccia in the base }\end{array}$ \\
\hline T13 & $\begin{array}{l}\text { Font de Bàlitx } \\
\text { d'Enmig } 1\end{array}$ & 2.73195 & 39.80529 & 367 & Mesozoic & $\begin{array}{l}\text { Upper Triassic } \\
\text { (Rhaetian) }\end{array}$ & $\begin{array}{l}\text { Lutites, sandstones, gypsum and } \\
\text { volcanic rocks }\end{array}$ \\
\hline
\end{tabular}


biofilm that grows on hard surfaces, such as rocks, pebbles or artificial substrates, was sampled by scraping it with a brush and resuspending the collected material in a tube with 25 $\mathrm{ml}$ of water from the environment. The sampling was extended to the surface of bryophytes, cormophytes and submerged or wet plant structures. For all the different substrates up to $10 \mathrm{~cm}^{2}$ were sampled whenever possible. The unit samples from each spring were fixed with $3.2 \mathrm{ml}$ of buffered formaldehyde $38-40 \%$, to obtain a final concentration of $\approx 4 \%$ and were kept at $4{ }^{\circ} \mathrm{C}$ until the final treatment and later analysis. In the laboratory, $5-10 \mathrm{ml}$ of sample were treated with the usual protocol for eliminating the cellular content with hydrogen peroxide. The frustules recovered by sedimentation were resuspended until the proper concentration (about 10-15 per field at $1000 \mathrm{x})$. Samples were mounted with Naphrax ${ }^{\circledR}$ in a permanent preparation and were examined in the POLYVAR microscope with the immersion objective $(1000 \mathrm{x})$. The present taxa were identified at lower taxonomical level whenever possible - with the help of different reference works (Krammer \& Lange-Bertalot, 1986, 1988, 1991a, 1991b; Lange-Bertalot, 2000-2003; Lange-Bertalot, 2003; Hofmann et al., 2011). At least 400 valves were counted in each sample.

Sampling of aquatic macroinvertebrates and microcrustaceans. For the collection of these organisms, after the identification of the different microhabitats present in each spring, a circular hand net $20 \mathrm{~cm}$ in diameter, with a mesh of 100 $\mu \mathrm{m}$, was used. This type of hand net is used in some of the current sampling protocols for the evaluation of the ecological status of the lenitic habitats (IBCAEL-2013 or QAELS 2010 ). Firstly, the pleustonic invertebrates were sampled, followed by the benthic ones. Microhabitats smaller than $2 \mathrm{~m}^{2}$ were thoroughly sampled, while up to $3 \mathrm{~m}^{2}$ were sampled in those with a higher surface. The sample collected was cleaned in situ through a $100 \mu \mathrm{m}$ sieve rinsed with water from the environment and, once the largest solid waste had been removed, it was introduced into a hermetic vial and fixed with buffered formalin (ca. concentration of $10 \%$ ). Once in the laboratory, the samples were passed through a column of sieves of $5 \mathrm{~mm}, 1 \mathrm{~mm}$ and $0.1 \mathrm{~mm}$ in order to separate organisms by size and facilitate the sorting of the specimens. All the samples were fully processed, without previous sub-sampling. The invertebrates were identified using a stereoscopic microscope with up to 60 magnifications, and using an optical microscope up to 1000 magnifications whenever necessary (mainly for microcrustaceans). Within the invertebrates, the microcrustaceans, characterised by their small size, were dissected and mounted under a stereoscopic microscope and their identification was carried out using an optical microscope (1000x). The taxonomic resolution was the lowest possible for the stage of the life cycle of the specimens. For their identification numerous taxonomic works specialised on the different groups of invertebrates were used (e.g. Branchiopoda: Alonso, 1996; Margaritora, 1985 - Coleoptera: Foster et al., 2011, 2014; Franciscolo, 1979; - Copepoda: Dussart, 1967, 1969 - Elmidae: Olmi, 1976; Berthélemy, 1979; Rico, 1992, 1998; Čiampor \& Kodada, 2010 - Hydraenidae: Balfour-Browne, 1978; Berthélemy, 1986; Lagar \& Fresneda, 1990; Garrido et al., 2004 - Odonata: Askew, 2004; Heidemann \& Seidenbush, 2002 Ostracoda: Henderson, 1990; Meisch, 2000 Trichoptera: Malicky, 2004; Waringer \& Graff, 2011, among others).

Sampling of vertebrates. The only group of vertebrate fauna that includes organisms which spend part of their life cycle in the aquatic environment are the amphibians, whose larvae live in very different types of still waters. To avoid collecting them, amphibians were identified in situ with the help of specific keys (Rivera, 2011). Other vertebrates that use the resources of the spring environment were determined basically from the traces and signals that they produce (on a few occasions they were directly observed).

\section{Diversity appraisal}

Biological richness, i.e. the number of taxa, was used as the indicator for both $\alpha$-diversity (in each spring) and $\gamma$-diversity (in each study area).

Several indicators for $\beta$-diversity were chosen to compare the taxa lists of different springs. Euclidean distance, Jaccard distance (Jaccard, 1901) and Bray-Curtis dissimilarity (Bray \& Curtis, 1957) allowed the determination of 
Table 3. Basic physico-chemical parameters of the sampled springs. Q: water discharge; T: water temperature; Cond.: water electrical conductivity; TDS: total dissolved solids; $\mathrm{O}_{2}$ : dissolved oxygen. * The temperature is skewed because the water is piped on the ground along $150 \mathrm{~m}$. Parámetros fisicoquímicos básicos de las fuentes objeto de estudio. Q: caudal; T: temperatura del agua; Cond.: conductividad del agua; TDS: sólidos disueltos totales; $\mathrm{O}_{2}$ : oxígeno disuelto del agua. * La temperatura se ve sesgada, porqué el agua circula entubada por la superficie durante $150 \mathrm{~m}$.

\begin{tabular}{|c|c|c|c|c|c|c|}
\hline Spring & $\mathrm{Q}(1 / \mathrm{s})$ & $\mathrm{T}\left({ }^{\circ} \mathrm{C}\right)$ & $\mathrm{pH}$ & Cond. $(\mu \mathrm{S} / \mathrm{cm})$ & TDS (ppm) & $\mathrm{O}_{2}(\mathrm{mg} / \mathrm{l})$ \\
\hline \multicolumn{7}{|l|}{ MONTSANT } \\
\hline M01-Font de Cavaloca & 2.460 & 15.3 & 7.40 & 368 & 111 & 8.70 \\
\hline M12-Font del Barranc & 1.100 & 17.2 & 8.11 & 1038 & 341 & 8.84 \\
\hline M15-Degotall del Clot del Cirer & 0.008 & 17.1 & 8.21 & 331 & 108 & 8.16 \\
\hline M19-Font del Mas de Sant Blai & 0.225 & 15.3 & 6.90 & 1146 & 355 & 7.51 \\
\hline M20-Font del Mas del Soleràs & 0.450 & 15.0 & 8.07 & 411 & 119 & 8.64 \\
\hline M23-Font Pregona & 0.167 & 15.5 & 7.19 & 410 & 124 & 8.89 \\
\hline M26-Font de les Planes & 0.788 & 17.3 & 7.32 & 891 & 296 & 8.68 \\
\hline M27-la Fonteta & 0.350 & 17.3 & 7.42 & 795 & 262 & 7.81 \\
\hline M35-Font de la Gleva & 1.250 & 15.4 & 7.29 & 474 & 131 & 8.65 \\
\hline M38-Font del Peret & 0.400 & 13.0 & 8.17 & 499 & 132 & 8.40 \\
\hline \multicolumn{7}{|l|}{ SERRA DE TRAMUNTANA } \\
\hline T01-Font de sa Menta & 1.450 & 17.1 & 7.28 & 979 & 323 & 9.60 \\
\hline T02-Font dels Albellons & 0.013 & 16.3 & 7.26 & 623 & 196 & 8.34 \\
\hline T03-Font des Puig Ferrer & 0.400 & 15.9 & 7.07 & 665 & 205 & 9.20 \\
\hline T06-Font de s'Olla & --- & 17.2 & 7.21 & 900 & 298 & 10.46 \\
\hline T08-Font des Pi & --- & 17.3 & 7.35 & 475 & 160 & 9.02 \\
\hline T09-Font de Muntanya & 0.060 & 16.1 & 7.50 & 802 & 266 & 9.59 \\
\hline T10-Font des Molinet & 0.350 & 15.3 & 7.18 & 529 & 148 & 9.23 \\
\hline T11-Font de l'Assarell & 0.950 & $22.0 *$ & 7.66 & 466 & 192 & 8.70 \\
\hline T12-Font de son Tries de Dalt & 0.840 & 16.0 & 7.72 & 545 & 170 & 10.75 \\
\hline T13-Font de Bàlitx d'Enmig 1 & 0.045 & 15.0 & 7.54 & 413 & 122 & 9.89 \\
\hline
\end{tabular}

$\beta$-diversity between each pair of springs. In addition, the true $\beta$-diversity (Whittaker, 1960) was also assessed in each study area as the ratio between $\gamma$ - and $\beta$-diversity

The Jaccard index, the one-complement of the Jaccard distance, was used to estimate the similarity between springs and study areas.

\section{RESULTS}

\section{Physico-chemical parameters}

The measurement of the flow discharge of the springs provided very variable results, ranging from $0.008 \mathrm{l} / \mathrm{s}$ to $2.460 \mathrm{l} / \mathrm{s}$. In two springs of the Serra de Tramuntana, the flow could not be measured, either because the water filled a pool with no effluent downstream (Font des Pi) or because the effluent circulated in an irrigation ditch where there was no opportunity to make any measure- ment (Font de s'Olla). However, in the latter case, the flow was high when compared with other springs. The springs of Montsant and Serra de Tramuntana show similar values for the basic physico-chemical variables (Table 3 ). These are low to medium mineralisation waters as judged by its conductivity (331-1146 $\mu \mathrm{S} / \mathrm{cm})$, from neutral to slightly alkaline ( $\mathrm{pH}$ range 6.9-8.2) and with upwelling temperature ranging from 13.0 to $17.3^{\circ} \mathrm{C}$. On the other hand, dissolved oxygen concentration is slightly higher in springs of Serra de Tramuntana (8.3-10.7 $\mathrm{mg} / \mathrm{l})$ than in those of Montsant (7.5-8.9 mg/1).

\section{Biological richness of Mediterranean spring systems}

\section{Cormophytes}

Floristic inventories show 135 taxa in Montsant 
(10-40 taxa per spring) and 102 taxa in Serra de Tramuntana (7-41 taxa per spring). The lists include a significant but variable proportion of hygrophilous or aquatic taxa, which rises in average to $42 \%$ in springs of Montsant (range $13-74 \%$ ) and to $30 \%$ in Serra de Tramuntana (range 10-40\%). Among the most frequent species in the studied environments (present in half or more of the springs) there are hygrophytes like Brachypodium sylvaticum, Sonchus maritimus subsp. aquatilis and Equisetum ramosissimum (Montsant), Pteridium aquilinum (Serra de Tramuntana), or Adiantum capillus-veneris (both areas), although taxa from the zonal vegetation predominate in the insular springs, particularly those from the holm oak forest. Regarding the chorology of the identified flora, there are important differences between the two zones studied. In both, Mediterranean taxa predominate, but Euro-Siberian taxa represent only $6.9 \%$ in Serra de Tramuntana and rise to $27.4 \%$ in Montsant. Finally, it is worth highlighting the seven endemic taxa found in the Serra de Tramuntana springs, five of which are exclusive to the Balearic Islands (Hypericum balearicum, Rhamnus alaternus var. latifolius, Rubia angustifolia, Sibthorpia africana and Smilax aspera var. balearica) and the other two of Tyrrhenian-Balearic distribution (Bellium bellidioides and Satureja microphylla subsp. filiformis).

\section{Bryophytes}

25 taxa were identified in Montsant (3-10 taxa per spring) and 31 in Serra de Tramuntana (3-10 taxa per spring). The taxa which can be considered hygrophilous/hydrophilous average $54 \%$ in Montsant (range 50-100 \%) and $42 \%$ in Serra de Tramuntana (range 22-100\%), higher than those shown by the vascular flora. Only two taxa of Serra de Tramuntana have been collected in half or more of the springs: Scorpiurium circinatum (7) and Eucladium verticillatum (5). In Montsant, the most frequent ones are Pellia endiviifolia (8), E. verticillatum (7), Cratoneuron filicinum (7) and Oxyrrhynchium speciosum (5).

\section{Macroalgae}

This group is the most diversified taxonomically speaking, since three biological kingdoms are represented in it: Eubacteria, Chromista and Plantae. A total of 40 taxa have been determined in Montsant (1-16 taxa per spring) and 46 taxa in Serra de Tramuntana (0-17 taxa per spring). In Montsant only three taxa have been found in half or more of the springs: Oedogonium sp. (7), Spirogyra cf. subsalsa (5) and Tolypothrix sp. (5), while in Serra de Tramuntana the most frequent algae are Oedogonium sp. (4), Tolypothrix cf. tenuis (4) and Zygnema sp. (4).

\section{Diatoms}

The richness of diatoms reaches 119 taxa in Montsant (19-42 taxa per spring), a figure that is much higher than the 82 taxa of Serra de Tramuntana (12-30 taxa per spring). From an ecological point of view, the majority of taxa are freshwater, benthic, alkaliphilous, and oligosaprobic or $\beta$-mesosaprobic. Many are common in fluvial environments (lenitic or lotic), but some taxa are crenophilous. Among these, Caloneis alpestris, Encyonopsis cesatii and Meridion circulare are found in both Montsant and Serra de Tramuntana, while Delicata delicatula (var. alpestris and var. angusta) and Eucocconeis flexella, have only been identified in the Montsant springs. We here report the first citations of Diploneis krammeri for the Iberian Peninsula (identified in eight springs of Montsant) and its second location in Mallorca, in Font des Molinet (cited in Font de s'Olla by Delgado et al., 2013). Finally, it should be noted that some frustules that could not be identified at a specific level could belong to new taxa, yet to be described.

Aquatic macroinvertebrates and microcrustaceans

This is the group that showed the highest taxonomic richness in the springs studied. We identified 168 taxa in Montsant (28-66 taxa per spring) and 101 taxa in Serra de Tramuntana (12-38 taxa per spring). Among them, the taxonomic richness of microcrustaceans reached 18 taxa in Montsant and 16 taxa in Serra de Tramuntana (1-6 taxa per spring in both areas). The richest group was insects, which represented $72 \%$ and $56 \%$ of taxa of Montsant and Serra de Tramuntana, respec- 
tively. The orders with greater representation were the dipterans, which contributed to $25 \%$ and $19 \%$ of the macroinvertebrate taxa found in the respective orographic units, and the water beetles, with $17 \%$ and $16 \%$. Among the taxa of interest, it is worth mentioning the amphipod crustacean Niphargus sp., a stygobiont that was identified in two springs of Montsant. Also, in Montsant, the invasive alien gastropod Potamopyrgus antipodarum, originally from New Zealand, was found in five springs.

\section{Vertebrates}

The only group of vertebrates that can be considered resident in the aquatic environment is that of amphibians. Usually these have been identified through direct observation. In Montsant, the presence of three amphibians has been documented: Alytes obstetricans (4 springs), Epidalea calamita (2 springs) and Pelophylax perezii (1 spring), while in Serra de Tramuntana only the last species was detected in three springs. For the rest of the vertebrates, Montsant has appeared to be a richer area than Serra de Tramuntana, where no other vertebrate species was detected apart from the amphibians. While several species of birds could be identified by direct observation, the recognition of signs has been useful in Montsant for the detection of wild boar, fox, badger and water vole in the spring environment. The richness thus obtained, observed directly or by means of signs, was limited to $0-10$ taxa.

\section{Biodiversity levels}

Mean alpha diversity (local diversity), as assessed in terms of biological richness, is higher in Montsant (113.0 \pm 23.8 ; range 82-152 taxa/spring) than in springs of Serra de Tramuntana (77.8 \pm 19.6 ; range 55-119 taxa/spring), and the difference is mainly due to the contribution of macroinvertebrates and diatoms (see above). Gamma diversity, that is the biological richness of each full set of springs is also higher in the first area (500) than in the second one (363).

There are various ways to estimate beta diversity, i.e. the extent of change in the taxa list between springs of the same area, and all of them yield a great extent of change (Table 4). Mean values for Jaccard distance, Bray-Curtis dissimilarity and true $\beta$-diversity are slightly higher between the springs of Serra de Tramuntana than between those of Montsant. On the contrary, Euclidean distance is higher in Montsant, most probably due to the significantly higher number of taxa.

Considering both study areas, mean alpha diversity would be $431.5 \pm 96.9$ and gamma diversity rises up to 711 taxa, being aquatic macroinvertebrates - including the microcrustaceans - (221 taxa), cormophytes (205 taxa) and diatoms (154 taxa) the most abundant biological groups. Thus, there is still an important extent of change, with values of beta diversity indices only slightly lower than the mean values obtained between individual springs (Table 4).

The results are illustrated in Figure 2 and the

Table 4. Diversity indices of the springs of Montsant and Serra de Tramuntana, as well as those of both study areas. For alpha diversity and for beta indices of Montsant and Serra de Tramuntana (excluding true beta) the mean value \pm standard deviation is given. Índices de diversidad de las fuentes de Montsant y Serra de Tramuntana, así como de ambas zonas de estudio. Para la diversidad alfa y para los índices beta de Montsant y Serra de Tramuntana (exceptuando la beta verdadera) se proporciona la media \pm desviación estándar.

\begin{tabular}{clccc}
\hline \multirow{2}{*}{ Diversity } & Index & MONTSANT $(\mathrm{n}=10)$ & SERRA DE TRAMUNTANA $(\mathrm{n}=10)$ & BOTH AREAS $(\mathrm{n}=2)$ \\
\hline $\boldsymbol{\alpha}$ & Biological richness $(\mathrm{S})$ & $113.0 \pm 23.8$ & $77.8 \pm 19.6$ & $431.5 \pm 96.9$ \\
\hline & Euclidean distance & $12.41 \pm 0.90$ & $10.66 \pm 0.78$ & 23.64 \\
$\boldsymbol{\beta}$ & Bray-Curtis dissimilarity & $0.688 \pm 0.076$ & $0.737 \pm 0.058$ & 0.645 \\
& Jaccard distance & $0.813 \pm 0.053$ & $0.848 \pm 0.039$ & 0.785 \\
& True $\beta$-diversity $(\gamma / \bar{\alpha})$ & 4.425 & 4.653 & 1.648 \\
\hline $\boldsymbol{\gamma}$ & Biological richness $(\mathrm{S})$ & 500 & 363 & 711 \\
\hline
\end{tabular}




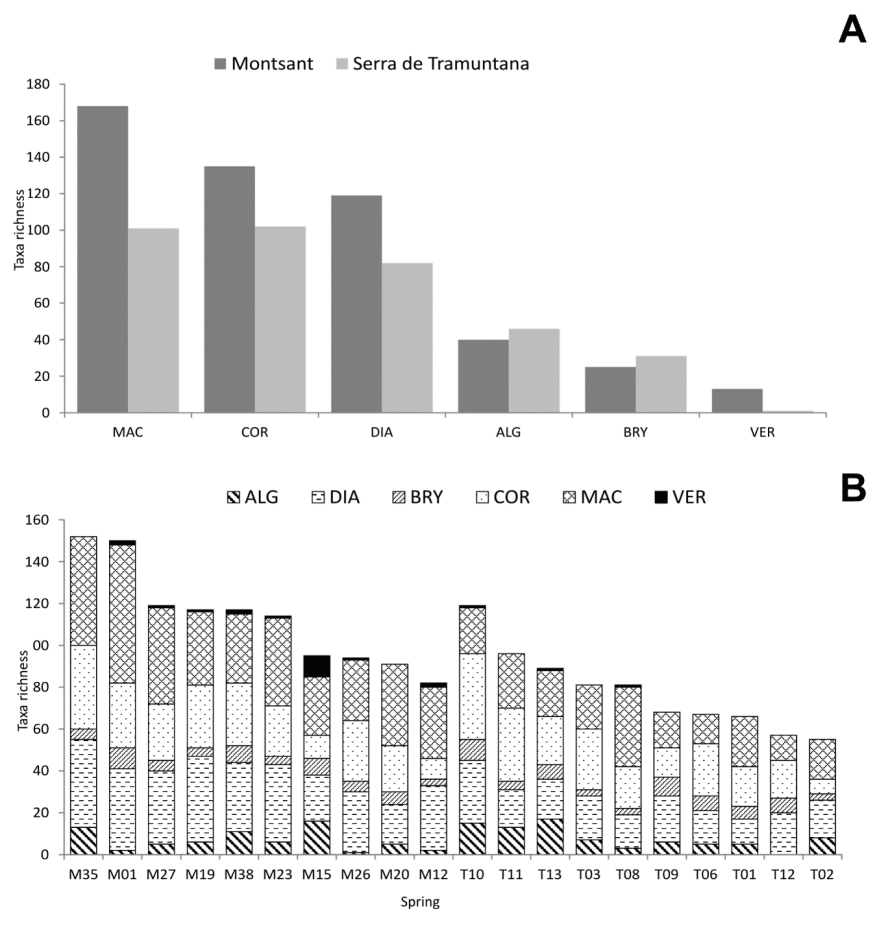

Figure 2. Bar diagram showing the biological richness achieved for the sampled springs. A. Richness of the different biological groups in the two study areas. B. Taxonomic richness of each spring. ALG: macroalgae; DIA: diatoms; BRY: bryophytes; COR: cormophytes; MAC: aquatic macroinvertebrates (including microcrustaceans); VER: vertebrates. The names of the springs are displayed in tables 1, 2 and 3. Gráfico de barras en donde se representa los valores de riqueza biológica obtenidos en las fuentes muestreadas. A. Riqueza de los distintos grupos biológicos en las dos zonas de estudio. B. Riqueza taxonómica de cada fuente. ALG: macroalgas; DIA: diatomeas; BRY: briófitos; COR: cormófitos; MAC: macroinvertebrados acuáticos (incluidos los microcrustáceos); VER: vertebrados. Los nombres de las fuentes pueden consultarse en las tablas 1, 2 y 3.

complete list of taxa in each spring can be found in the supplementary material, Tables S1 and S2, available at http://www.limnetica.net/en/ limnetica.

\section{Level of biotic similarity of the springs}

Taking into account all the organisms identified, up to $52.2 \%$ of the taxa of Montsant and $50.1 \%$ of those of Serra de Tramuntana were only found in one spring; in the set of both zones, the proportion of organisms only found in one of the 20 springs reached $48.8 \%$. On the contrary, the proportion of organisms found in half or more of the localities studied was remarkably low: $12.6 \%$ in Montsant, $9.1 \%$ in Serra de Tramuntana and only $3.2 \%$ considering both study areas.

The proportion of the number of matching taxa respect to the number of taxa identified in each pair of compared springs (using the Jaccard index $-J$ ), has values between 0.081 and 0.291 in the case of Montsant (mean: $0.187 \pm 0.053$ ), and between 0.063 and 0.238 in Serra de Tramuntana (mean: $0.152 \pm 0.040$ ). The values are lower if we compare the springs of both zones, between 0.049 and 0.167 (mean: $0.098 \pm 0.026$ ), but it should be stressed that there was a greater biotic coincidence between some pairs of springs of Montsant and Serra de Tramuntana than between other pairs belonging to the same area. In Montsant (Fig. 3) a significant, though modest, inverse correlation between $\mathrm{J}$ and the difference in altitude is observed $(\mathrm{r}=-0.580 ; p<0.01)$, but not in Serra de Tramuntana $(\mathrm{r}=-0.173 ; p>0.05)$. In both areas $\mathrm{J}$ value correlates inversely and very weakly with the distance between the springs (Montsant: $\mathrm{r}=-0.297, p<0.05$; Serra de Tramuntana: $\mathrm{r}=-0.343, p<0.05$ ). 

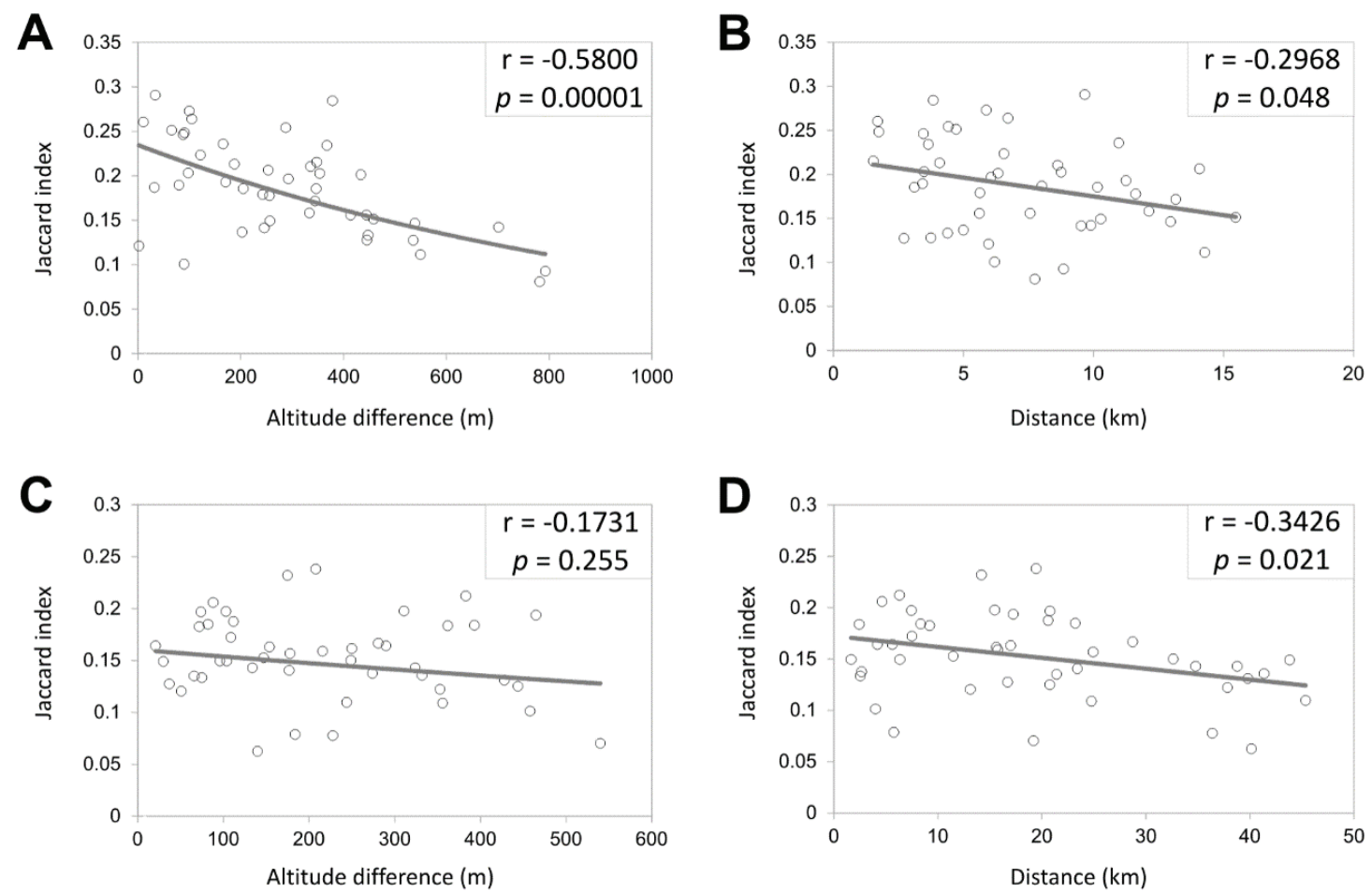

Figure 3. Correlation diagrams of the similarity of biological taxa, as calculated by means of Jaccard index (J), with both the difference in topographic altitude and the distance between each couple of springs from Montsant (A, B) and Serra de Tramuntana (C, D). The correlation index $r$ and the p-value are provided. Diagramas de correlación de la similitud de taxones biológicos, calculada mediante el indice de Jaccard (J), con la diferencia de altitud topográfica y con la distancia entre cada par de fuentes de Montsant (A, $B)$ y de la Serra de Tramuntana $(C, D)$. Se proporciona el índice de correlación r y el valor de p.

\section{DISCUSSION}

The data provided in this study constitute the first integral approach to the biocenotic structure and the biological richness of Mediterranean spring ecosystems, both continental and insular, and confirm that the spring environments are exceptional sources of biodiversity, given that extremely rich biocenoses that could harbour a large part of continental and insular biological diversity develop in a very small area. The biological richness values found are close to those reported by Cantonati \& Ortler (1998) from the systematic sampling of a very similar taxonomic spectrum in the Adamello-Brenta Park (Southeast Alps, 1073-2172 m), in the Euro-Siberian biogeographical region, where they identified 730 taxa in 19 or 30 springs, depending on the biological group (50-113 taxa per spring). The three biological groups with highest richness match with those found in our work (Fig. 4), although in an inverse order: in the Alps, the richest group was the diatoms (250 taxa) followed by the cormophytes (245 taxa) and the macroinvertebrates (137 taxa). It should be noted that the overall results conceal a significant fact: without considering vertebrates, a group not addressed in Alpine springs, six out of the 20 Mediterranean springs investigated have a biological richness higher than the maximum reached in Alpine springs.

Concerning vertebrates, in addition to those dwelling in aquatic habitats (amphibians), we took into account terrestrial species which use the springs by recognising signs or through direct observation. However, these methods are not sensitive enough to be considered exhaustive. To approach the vertebrate species which visit crenic environments, after obtaining the corresponding 


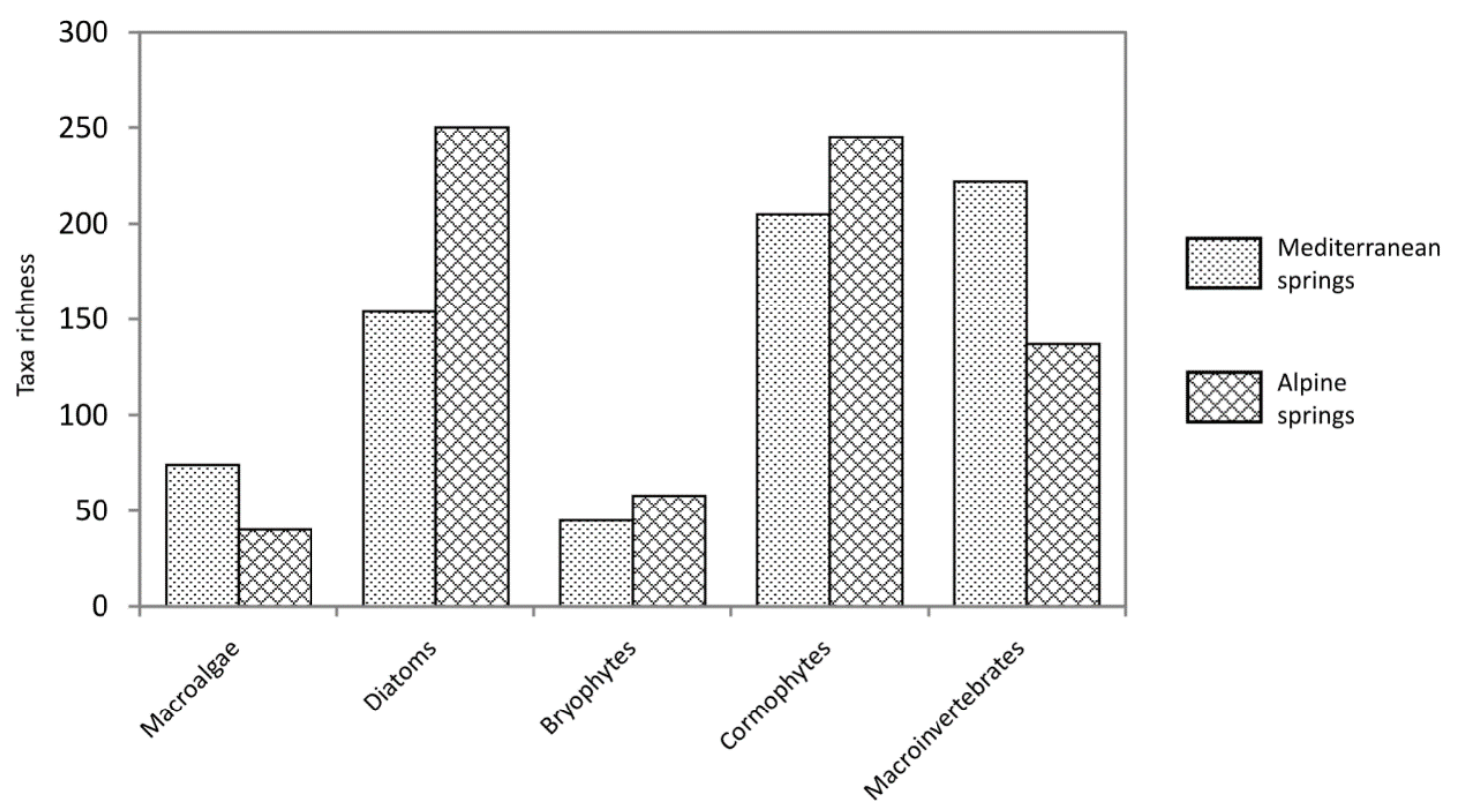

Figure 4. Comparison of the taxonomic richness of different biological groups in Mediterranean (this study) and Alpine (Cantonati \& Ortler, 1998) springs. The amount of Alpine springs studied is 30 for diatoms and some groups of macroinvertebrates (water mites, microcrustaceans and gastropods) and 19 for cormophytes, macroalgae, bryophytes and the rest of macroinvertebrates. Comparación de la riqueza taxonómica de distintos grupos biológicos en fuentes mediterráneas (este estudio) y alpinas (Cantonati \& Ortler, 1998). El número de fuentes alpinas estudiadas es de 30 para las diatomeas y algunos grupos de macroinvertebrados (hidrácaros, microcrustáceos y gasterópodos) y de 19 para cormófitos, macroalgas, briófitos y el resto de macroinvertebrados.

permissions, we placed a camera trap in a spring - not included in this study - over five daily cycles. This test allowed us to confirm that camera recording is the most effective way of performing systematic inventories of the vertebrates that make use of the springs. It is particularly useful for birds, as they rarely leave any trace.

One of the peculiarities of the Mediterranean springs is their function as a refuge for Euro-Siberian taxa, by eliminating or decreasing the summer drought in its immediate surroundings. In the springs of Montsant, these represent $27.4 \%$ of the vascular flora, compared to $22.2 \%$ in the whole massif (Pascual, 2007), which undoubtedly contributes to cormophyte richness being, on a small scale, much higher than in the zonal vegetation. The richness of bryophytes is much lower, comparable to that reported in a recent study from springs in eastern Catalonia, where 1 to 12 taxa per spring were identified (Bes et al., 2017). In Euro-Siberian and Alpine bioclimates the bryophyte richness is greater, as evidenced by the works of Cantonati \& Ortler (1998), who identified 58 taxa in 19 springs in the south-eastern Alps, and Weigand (1998), 77 taxa in 22 springs of the Austrian Alps, as compared to the 45 taxa determined in the 20 Mediterranean springs of this study. On the other hand, the greater or lesser participation of hygrophilous/hydrophilous vascular plants and bryophytes in the courtship of each spring seems to be related to water extraction and the effectiveness of transport and storage associated structures as, for their development, the presence of more or less permanently wet substrata is necessary. In this sense, the springs of Serra de Tramuntana, in general more regulated by these structures than those of Montsant, have a lower percentage of hygrophytes/hydrophytes.

The richness of macroalgae is highly variable and seems to be related to the number of suitable microhabitats and the effective illumination on them, as other authors reported (Cantonati et al., $2012 \mathrm{~b}$ ). The lowest rates occur in springs located in a forest environment (low lighting) and that do not 
generate aquatic environments (water masses or wet surfaces) of sufficient size. The overall value of the present study (74 taxa in the 20 springs) is notoriously higher than the one found by Cantonati et al. (2012b) in springs from the south-eastern Alps (47 taxa in 70 springs) or by Stevenson et al. (2007) in Florida (23 taxa in 29 springs).

The group of diatoms has been the most profusely studied in springs, with results comparable to those reported here. There are data from the springs of the Alps, the Carpathians, Poland, Switzerland, France, Belgium, Sardinia or Galicia. Other works have explored geographic areas near ours, like Sabater \& Roca (1992), who identified 192 taxa in 28 Pyrenean springs between 670 and $2000 \mathrm{~m}$ or Aboal et al. (1998), who determined 145 taxa in 135 springs of the province of Castelló (0-1340 m). Delgado et al. (2013) were able to classify 111 taxa in two springs (Font de s'Olla and Font des Pi, also included in this study) and four spring-fed streams in Mallorca. These data, together with the results of other studies of springs in Alps and various places of the central and western Europe, allow affirming that, on the one hand, the richness of diatoms contributed by all the studies is closely related to the number of springs sampled and, on the other hand, the courtship of species and their abundance in a locality can vary considerably throughout the year. In Font de s'Olla (T06) Delgado et al. (2013) found as most abundant taxa (>5\%) Achnanthidium minutissimum, Amphora pediculus, Diadesmis contenta and Plantothidium frequentissimum. The first two are also abundant in this work, while D. contenta has not been identified in our sample and $P$. frequentissimum does not reach $5 \%$ of the frustules $(3.68 \%)$. On the contrary, Ulnaria ulna and Encyonopsis minuta, which surpass $5 \%$ in our results, were found only sparingly $(<1.5 \%)$ in the cited reference. In the case of Font des Pi, Delgado et al. found abundant the taxa A. minutissimum, Achnanthidium pyrenaicum, Denticula tenuis, Diadesmis contenta, Encyonopsis krammeri and Navicula reichardtiana. Only the first two also abound in our sample. In contrast, E. krammeri is frequent and D. tenuis is rare, whereas $D$. contenta and $N$. reichardtiana have not appeared. We found E. minuta very abundant and Gomphonema lateripunctatum abundant: only the latter appeared sparsely in the samples of Delgado et al. As in the majority of bibliographic references (e.g. Angeli et al., 2010, Mogna et al., 2015), the most diversified genera are Nitzschia, Navicula, Gomphonema and Cymbella. On the other hand, Achnanthidium minutissimum has been identified in all the springs studied, which coincides with its high frequency in Alpine springs (Cantonati \& Lange-Bertalot, 2010, Gesierich \& Kofler, 2010, Mogna et al., 2015).

The overall results for aquatic macroinvertebrate and microcrustacean richness are similar to those in other published works, but the richness exhibited by the springs of Montsant (average of 40 taxa per spring) is only slightly surpassed by the results of Webb et al. (1995) in ten springs at Sinkhole Plain, Illinois (average of 42 taxa per spring) and clearly exceeds the average values per spring in New Zealand (16 taxa per spring, Scarsbrook et al., 2007), Shawnee Hills, Illinois (27 taxa per spring, Webb et al., 1995), Devils Tower, Wyoming (18 taxa per spring, Tronstad \& Griscom, 2012), or Monti della Laga, central Apennines (16 taxa per spring, Di Sabatino et al., 2009) - values closer to the average richness found in the springs of Serra de Tramuntana (21.5 taxa per spring).

Several authors have underlined the low coincidence in the lists of taxa of certain biological groups, even among nearby springs in space with close ecological characteristics. In the south-eastern Alps, Bonettini \& Cantonati (1996) highlighted this for macroinvertebrates, Maiolini et al. (2011), for Plecoptera and Trichoptera, and Lencioni et al. (2011) for Chironomidae. In Belgium, Denys \& Oosterlynck (2015) reported the same for diatoms. This phenomenon is evident in the different biological groups addressed in this study because of the low frequency of appearance of most taxa. In this regard, the results obtained in the diversity and similarity analyses seem to reinforce the hypothesis, already pointed out by other authors, that each spring environment could have a particular and characteristic community. However, alternatively, they could indicate the insufficiency of sampling protocols used to catch the entire biological richness, at least for certain groups. On the one hand, several studies have demonstrated 
the seasonal variability of crenocenoses, specifically in the case of diatoms (Cantonati, 1998, Lai et al., 2016). In addition, the sampling effort and the time devoted to the analysis of the samples should also be considered: for example, a longer time and effort should be spent to detect the less frequent taxa of diatoms, which can represent a significant fraction of the richness (Angeli et al., 2010). In any case, the consequences derived from the results obtained are of the greatest interest: if the different springs really share only a small fraction of the biological richness between them, it would mean that each spring ecosystem is unique and unrepeatable; if, on the contrary, the differences were due mainly to the insufficiency of the sampling methods, springs would constitute even more exceptional hot spots of biodiversity, since the biological richness found in most studies, already very high on its own, would clearly be underestimated.

The circum-Mediterranean biogeographical arch is the region historically subjected to a greater anthropic transformation. Additionally, given the implicit singularities of the Mediterranean climate and its expression in the water cycle and in the aquatic environments dependent on this cycle, it seems likely that the Mediterranean springs could be especially sensitive to the climate change of anthropogenic origin that is being reported in the scientific literature. The climate alterations, in concomitance with other pressures, could be slowly and silently modelling the biological richness of Mediterranean springs. In relation to this, the present study notes the worrying lack of data and scientific knowledge about the operation and the ecological role played by the Mediterranean spring ecosystems with respect to the biological richness that depends on it.

All this draws a paradoxical scenario in the field of conservation biology: the striking contrast among the importance of springs (biodiversity hot spots, biological reservoirs, ecosystem services...), their vulnerability (climate change, physical fragility...), the lack of any specific legal protection and the poor knowledge of how they should be managed. The conservation of the spring ecosystems should be placed as one of the priorities in the agenda of the policies and strategies of biodiversity conservation for the upcoming years. In this context, the involvement of protected natural areas in their direct management on the ground will be of the utmost importance.

\section{ACKNOWLEDGEMENTS}

The island studies 2017-2018 were financed by the Ministerio para la Transición Ecológica, through Fundación Biodiversidad, and Govern de les Illes Balears. The continental studies in 2012-2016 received funds from the Generalitat de Catalunya and Diputació de Tarragona, as well as the collaboration of MN Consultors en Ciències de la Conservació, while in 2017-2018 were financed by the Ministerio para la Transición Ecológica through Fundación Biodiversidad.

We are indebted to the personnel of the Servei d'Espais Naturals (Conselleria de Medi Ambient, Agricultura i Pesca, Govern de les Illes Balears), Paratge Natural de la Serra de Tramuntana and Parc Natural de Montsant, for their support to the project and valuable suggestions that contributed to improve it.

\section{REFERENCES}

ABOAL, M., A. M. PUIG \& M. PREFASI. 1998. Diatom assemblages in springs in Castellón province, Eastern Spain. Algological Studies, 90: 79-95.

ALONSO, M. 1996. Crustacea Branchiopoda. Fauna Iberica, vol. 7. Madrid: Museo Nacional de Ciencias Naturales, 486 pp.

ANGELI, N., M. CANTONATI, D. SPITALE \& H. LANGE-BERTALOT. 2010. A comparison between diatom assemblages in two groups of carbonate, low-altitude springs with different levels of anthropogenic disturbances. Fottea, 10 (1): 115-128. DOI: $10.5507 /$ fot. 2010.006

ASKEW, R. R. 2004. The Dragonflies of Europe. Harley Books, Colchester, UK.

BALFOUR-BROWNE, J. 1978. Studies on the Hydraenidae (Coleoptera) of the Iberian Peninsula. Ciência Biológica 4: 53-107.

BELLINGER, G. \& C. SIGEE. 2010. Freshwater Algae: Identification and Use as Bioindicators. John Wiley \& Sons, Ltd. DOI: 10.1002/9780470689554 
BERTHÉLEMY, C. 1979. Elmidae de la région paléarctique occidentale: systématique et répartition (Coleoptera, Dryopoidea). Annales de Limnologie, 15 (1): 1-102. DOI: 10.1051/ limn/1979014

BERTHÉLEMY, C. 1986. Remarks on the genus Hydraena. and revision of the subgenus Phothydraena (Coleoptera : Hydraenidae). Annales de Limnologie, 22 (2): 181-193. DOI: 10.1051/limn/198601

BES, M., J. CORBERA, F. SAYOL, G. BAGARIA, M. JOVER, C. PREECE, F. SABATER, A. VIZA \& M. FERNÁNDEZ-MARTÍNEZ. 2017. Efecte de les variables ambientals i hidrològiques sobre la riquesa i distribució dels briòfits fontinals a la Catalunya oriental. Butlletí de la Institució Catalana d'Història Natural, 81: 121-134.

BOLÒS, O. \& J. VIGO. 1984-2001. Flora dels Països Catalans (vol. I-IV). Ed. Barcino, Barcelona.

BONETTINI, A. M. \& M. CANTONATI. 1996. Macroinvertebrate assemblages of springs of the River Sarca catchment (Adamello-Brenta Regional Park, Trentino, Italy). Crunoecia, 5: 71-78.

BOTOSANEANU, L. 1995. Springs as refugia for geographic relicts. Crunoecia, 4, 5-9.

BRAY, J. R. \& J. T. CURTIS. (1957). An ordination of upland forest communities of southern Wisconsin. Ecological Monographs, 27: 325-349.

CANTONATI, M. 1998. Diatom communities of springs in the Southern Alps. Diatom Research, 13: 201-220. DOI: 10.1080/0269249X.1998. 9705449

CANTONATI, M. \& K. ORTLER. 1998. Using spring biota of pristine mountain areas for long term monitoring. Hydrology, Water Resources and Ecology in Headwaters (Proceedings of the Headwater'98 Conference held at Merano/Meran, Italy, April 1998). IAHS Publ. 248: 379-385.

CANTONATI, M., R. GERECKE \& E. BERTUZZI. 2006. Springs of the Alps-sensitive ecosystems to environmental change: from biodiversity assessments to long-term studies. Hydrobiologia, 562: 59-96. DOI: 10.1007/ s10750-005-1806-9
CANTONATI, M. \& H. LANGE-BERTALOT. 2010. Diatom biodiversity of springs in the Berchtesgaden National Park (North-eastern Alps, Germany), with the ecological and morphological characterization of two species new to science. Diatom Research, 25 (2): 251-280. DOI: 10.1080/0269249X.2010. 9705849

CANTONATI, M., L. FÜREDER, R. GERECKE, I. JÜTTNER \& E. J. COX. 2012a. Crenic habitats, hotspots for freshwater biodiversity conservation: toward an understanding of their ecology. Freshwater Science, 31: 463-480. DOI: 10.1899/11-111.1 CANTONATI, M., E. ROTT, D. SPITALE, N. ANGELI \& J. KOMÁREK. 2012b. Are benthic algae related to spring types? Freshwater Science, 31 (2):481-498. DOI: 10.1899/11-048.1

CASAS, C., M. BRUGUÉS \& R. M. CROS. 2004. Flora dels briòfits dels Països Catalans (vol. I i II). Institut d'Estudis Catalans, Barcelona.

CASAS, C., M. BRUGUÉS, R. M. CROS \& C. SÉRGIO. 2006. Handbook of Mosses of the Iberian Peninsula and the Balearic Islands. Institut d'Estudis Catalans, Barcelona.

ČIAMPOR Jr, F. \& J. KODADA. 2010. Taxonomy of the Oulimnius tuberculatus species group (Coleoptera: Elmidae) based on molecular and morphological data. Zootaxa, 2670: 59-68. DOI: 10.11646/zootaxa.2670.1.4

CIRUJANO, S. (ed.). 2007. Flora Ibérica. Algas continentales. Carófitos (Characeae). Real Jardín Botánico. Madrid.

DELGADO, C., L. ECTOR, M. H. NOVAIS, S. BLANCO, L. HOFFMANN \& I. PARDO. 2013. Epilithic diatoms of springs and spring-fed streams in Majorca Island (Spain) with the description of a new diatom species Cymbopleura margalefii sp. nov. Fottea, 13(2): 87-104. DOI: 10.5507/fot.2013.009

DENYS, L. \& P. OOSTERLYNCK. 2015. Diatom assemblages of non-living substrates in petrifying Cratoneurion springs from lower Belgium. Fottea, Olomouc, 15(2): 123-138. DOI: $10.5507 /$ fot 2015.014

DI SABATINO, A., B. CICOLANI \& R. GERECKE. 2003. Biodiversity and distribution of water mites (Acari, Hydrachnidia) in 
spring habitats. Freshwater Biology, 48: 2163-2173. DOI: 10.1046/j.1365-2427.2003. 01151.x

DI SABATINO, A., P. BRUNI, F. P. NICCOLI, M. GIUSTINI, P. VIGNINI, G. TIMPERI \& B. CICOLANI. 2009. Diversità delle comunità macrobentoniche e qualità ambientale delle sorgenti dei Monti della Laga (Parco Nazionale Gran Sasso - Laga, Appennino centrale). Studi Trentini di Scienze Naturali, 84: 43-51.

DUSSART, B. 1967. Les Copépodes des Eaux Continentales d'Europe Occidentale, Part 1: Calanoides et Harpacticoides. N. Boubée \& Cie, Paris. DOI: 10.1002/iroh.19680530126

DUSSART, B. 1969. Les Copépodes des Eaux Continentales d'Europe Occidentale, Part 2: Cyclopoides et Biologie. N. Boubée \& Cie, Paris. DOI: 10.1002/iroh.19710560134

FIASCA, B., F. STOCH, M. J. OLIVIER, C. MAAZOUZI, M. PETITTA, A. DI CIOCCIO \& D. M. P. GALASSI. 2014. The dark side of springs: what drives small-scale spatial patterns of subsurface meiofaunal assemblages? Journal of Limnology, 73: 71-80. DOI: 10.4081/jlimnol.2014.848

FOSTER, G., D. BILTON \& L. FRIDAY. 2011. Keys to adults of the water beetles of Britain and Ireland (Part 1). Handbook for the Identification of British Insects. Vol. 4, Part 5 (2nd Ed.). Field Studies Council for the Royal Entomological Society, London.

FOSTER, G., D BILTON, \& L. FRIDAY. 2014. Keys to adults of the water beetles of Britain and Ireland (Part 2). (Coleoptera: Polyphaga: Hydrophiloidea-both aquatic and terrestrial species). Handbooks for the Identification of British Insects 4(5b). Royal Entomological Society, London.

FRANCISCOLO, M. E. 1979. Coleoptera: Haliplidae, Hygrobiidae, Gyrinidae, Dytiscidae. Fauna d'Italia, 14, Calderini, Bologna.

GARRIDO, J., L. F. VALLADARES \& J. A. DÍAZ. 2004. Taxonomy and Iberian distribution of Hydraena bisulcata Rey and Hydraena barrosi d'Orchymont (Coleoptera: Hydraenidae). Aquatic Insects, 26: 115-122. DOI: 10.1080/01650420412331325846

GERECKE, R., C. MEISCH, F. STOCH, F.
ACRI \& H. FRANZ. 1998. Eucrenon-hypocrenon ecotone and spring typology in the Alps of Berchtesgaden (Upper Bavaria, Germany). A study of microcrustacea (Crustacea: Copepoda, Ostracoda) and water mites (Acari: Halacaridae, Hydrachnellae). In: Studies in crenobiology. The biology of springs and springbrooks. L. Botosaneanu (ed.): 167-182. Backhuys Publ., Leiden. DOI: 10.1002/iroh. 19980830519

GESIERICH, D. \& W. KOFLER. 2010. Epilithic diatoms from rheocrene springs in the Eastern Alps (Vorarlberg, Austria). Diatom Research, 25(1):43-66. DOI: 10.1080/0269249X.2010. 9705828

GIBERT, J., M. J. DOLE-OLIVER, P. MARMONIER \& P. VERVIER. 1991. Surface Water-Groundwater Ecotones. In: Naiman, R.J. \& Décamps, H. (eds.): The Ecology and management of aquatic-terrestrial ecotones: 199-225. Paris: United Nations Educational, Scientific and Cultural Organization.

GUERRA, J., M. J. CANO \& R. M. CROS (eds.). 2006. Flora Briofítica Ibérica, Vol. III. Pottiales, Encalyptales. Universidad de Murcia. Sociedad Española de Briología.

GUERRA, J., M. BRUGUÉS, M. J. CANO \& R. M. CROS (eds.). 2010. Flora Briofitica Ibérica. Vol. IV. Funariales, Splachnales, Schistostegales, Bryales, Timmiales. Universidad de Murcia. Sociedad Española de Briología.

GUERRA, J., M. J. CANO \& M. BRUGUÉS (eds.). 2014. Flora Briofitica Ibérica. Vol. V. Ortotrichales, Hedwigiales, Leucodontales, Hookeriales. Universidad de Murcia. Sociedad Española de Briología.

GUIJARRO, J. 1986. Contribución a la Bioclimatología de Baleares. $\mathrm{PhD}$ thesis. Universitat de les Illes Balears, 2 vol., 282 y 301 pp.

HATTON, T. \& R. EVANS. 1998. Dependence of Ecosystems on Groundwater and its Significance to Australia. Occasional Paper No 12/98. Land and Water Resources Research and Development Corporation, Canberra.

HEIDEMANN, H. \& R. SEIDENBUSH. 2002. Larves et Exuvies des Libellules de France et d'Allemagne (sauf de Corse). Société Française d'Odonatologie, Bois d'Arcy.

HENDERSON, P. A. 1990. Freshwater Ostra- 
cods. Synopses of the British Fauna (New Series), 42 (Eds D.M. Kermack and R.S.K. Barnes), pp. 1-228. Universal Book Services \& Dr W. Backhuys, Oegstgeest.

HOFMANN, V. G., M. WERUM \& H. LANGE-BERTALOT. 2013. Diatomeen im Süßwasser - Benthos von Mitteleuropa. Bestimmungsflora Kieselalgen für die ökologische Praxis. Über 700 der häufigsten Arten und ihre Ökologie. VEB Gustav Fischer Verlag: Jena.

JACCARD, P. 1901. Étude comparative de la distribution florale dans une portion des Alpes et des Jura. Bulletin de la Société Vaudoise des Sciences Naturelles, 37: 547-579.

JOHN, D. M., B. A. WHITTON \& A. J. BROOK (eds.). 2005. The Freshwater Algal Flora of the British Isles. Cambridge University Press.

KOMÁREK, J. \& K. ANAGNOSTIDIS. 2008. Freshwater Flora of Central Europe. Vol. 19/2 Cyanoprokariota. Part 2: Oscillatoriales. Spektrum Akademischer Verlag, Heidelberg.

KRAMMER, K. \& H. LANGE-BERTALOT. 1986. Bacillariophyceae. 1. Teil: Naviculaceae. In: Süsswasser flora von Mitteleuropa, Band 2/1, Ettl, H., Gerloff, J., Heynig, H. and Mollenhauer, D. (eds). Gustav Fischer Verlag: Stuttgart, New York.

KRAMMER, K. \& H. LANGE-BERTALOT. 1988. Bacillariophyceae. 2. Teil: Bacillariaceae, Epithemiaceae, Surirellaceae. In: Süsswasser flora von Mitteleuropa, Band 2/2, Ettl, H., Gerloff, J., Heynig, H. and Mollenhauer, D. (eds). VEB Gustav Fischer Verlag: Jena.

KRAMMER, K. \& H. LANGE-BERTALOT. 1991a. Bacillariophyceae. 3. Teil: Centrales, Fragilariaceae, Eunotiaceae. In: Süsswasser flora von Mitteleuropa, Band 2/3, Ettl, H., Gerloff, J., Heynig, H. and Mollenhauer, D. (eds). Gustav Fischer Verlag: Stuttgart, Jena.

KRAMMER, K. \& H. LANGE-BERTALOT. 1991b. Bacillariophyceae. 4. Teil: Achnanthaceae, Kritische Ergänzungen zu Navicula (Lineolatae) und Gomphonema, Gesamtliteraturverzeichnis Teil 1-4. In: Süsswasser flora von Mitteleuropa, Band 2/4, Ettl, H., Gärtner, G., Gerloff, J., Heynig, H. and Mollenhauer, D. (eds). Gustav Fischer Verlag: Stuttgart, Jena.

LAGAR, A. \& X. FRESNEDA. 1990. Notas faunísticas y taxonómicas sobre Hydraenidae (Coleoptera, Palpicornia\} de la Península Ibérica: descripción de nuevas Hydraena ibéricas. Bulletin de l'Institut Royal des Sciences Naturelles de Belgique, 60: 149-160. LAI, G. G., B. M. PADEDDA, C. E. WETZEL, A. LUGLIÈ, N. SECHI \& L. ECTOR. 2016. Epilithic diatom assemblages and environmental quality of the Su Gologone karst spring (centraleastern Sardinia, Italy). Acta Botanica Croatica, 75 (1): 129-143. DOI: 10.1515/botcro-2016-0008

LANGE-BERTALOT, H. (ed.). 2000-2003. Diatoms of the European Inland Waters and Comparable Habitats. Vol. 1-4. A.R.G. Gantner Verlag K.G., Ruggell.

LANGE - BERTALOT, H., P. CAVACINI, N. TAGLIAVENTI \& S. ALFINITO. 2003 Diatoms of Sardinia. Rare and 76 new species in rock pools and other ephemeral waters. In: Annotated Diatom Monographs Vol.12. Lange - Bertalot, H. (ed).

LENCIONI, V., L. MARZIALI \& B. ROSSARO. 2011. Diversity and distribution of chironomids (Diptera, Chironomidae) in pristine Alpine and pre-Alpine springs (Northern Italy). In: M. Cantonati, R. Gerecke, I. Jüttner and E.J. Cox (Guest Editors) Springs: neglected key habitats for biodiversity conservation. Journal of Limnology, 70(Suppl. 1): 106-121. DOI: 10.4081/jlimnol.2011.s1.106

MAIOLINI, B., M. CAROLLI \& L. SILVERI. 2011. Ephemeroptera, Plecoptera and Trichoptera in springs in Trentino (south-eastern Alps). In: M. Cantonati, R. Gerecke, I. Jüttner and E.J. Cox (guest eds.) Springs: neglected key habitats for biodiversity conservation. Journal of Limnology, 70 (Suppl. 1): 122-133. DOI: 10.3274/JL11-70-S1-09

MALICKY, H. 2004. Atlas of European Trichoptera. Dr. W. Junk Publishers. The Hague. DOI: $10.1007 / 978-1-4020-3026-0$

MARGALEF, R. 1983. Limnología. Ed. Omega, Barcelona.

MARGARITORA, F.G. 1985. Cladocera. Fauna d'Italia. Edizioni Calderoni, Bologna.

MEISCH, C. 2000. Freshwater Ostracoda of Western and Central Europe. Spektrum Akademischer Verlag GmbH,Heidelberg, 
Berlin, $522 \mathrm{p}$.

MOGNA, M., M. CANTONATI, F. ANDREUCCI, N. ANGELI, G. BERTA \& L. MISERERE. 2015. Diatom communities and vegetation of springs in the south-western Alps. Acta Botanica Croatica, 74 (2), 265-285. DOI: 10.1515/botcro-2015-0024

NINYEROLA, M, X. PONS \& J.M. ROURE. 2001. Atles climàtic digital de Catalunya $(A C D C)$. Departament de Geografia de la Universitat Autònoma de Barcelona, Servei Meteorològic de Catalunya i Departament de Medi Ambient i Habitatge (Generalitat de Catalunya). http://www.opengis.uab.cat/acde/ [accessed 27/04/2018].

ODUM, E. P. 1971. Fundamentals, of ecology. 3rd edition. W. B. Saunders, Philadelphia.

OLMI, M. 1976. Coleoptera. Dryopidae, Elminthidae. Fauna d'Italia vol. XII. Calderini. Bologna.

PASCUAL, R. 2007. Flora de la Serra de Montsant. Vol. I y II. Rafael Dalmau Editor, Barcelona.

REISS, M. 2013. An integrative hierarchical spatial framework for spring habitats. Journal of Landscape Ecology, 6(2): 65-77. DOI: 10.2478/v10285-012-0068-2

REISS, M. \& P. CHIFFLARD. 2015. Hydromorphology and Biodiversity in Headwaters An Eco-Faunistic Substrate Preference Assessment in Forest Springs of the German Subdued Mountains. In: Lo, Y.H., J.A. Blanco \& S. Roy (eds.) Biodiversity in Ecosystems Linking Structure and Function: 223-258. Rijeka: InTech. DOI: 10.5772/59072

RICO, E. 1992. Los Elmidae (Coleoptera: Dryopoidea) de la Península Ibérica e Islas Baleares. Estudio faunístico y análisis de los factores históricos y ecológicos que condicionan su distribución. Tesis Doctoral, Universidad del País Vasco.

RICO, E. 1998. A revision of the Limnius perrisi subspecies group (Coleoptera, Elmidae) in the Iberian Peninsula. Aquatic Insects, 20: 133-139. DOI: 10.1076/aqin.20.3.133.4478

RIVAS-MARTÍNEZ, S. \& S. RIVAS-SÁENZ. 1996-2009. Sistema de Clasificación Bioclimática Mundial. Centro de Investigaciones Fitosociológicas, España. http://www. ucm.es/info/cif [accessed 27/04/2018].

RIVERA, X., D. ESCORIZA, J. MALUQUERMARGALEF, O. ARRIBAS \& S. CARRANZA. 2011. Amfibis i rèptils de Catalunya, País Valencià I Balears. Lynx edicions, Barcelona. ROSATI, M. 2016. Assembly processes of invertebrate communities in springs across different spatial scales. $\mathrm{PhD}$ thesis. University of Parma.

SABATER, S. \& J. R. ROCA. 1992. Ecological and Biogeographical Aspects of Diatom Distribution in Pyrenean Springs. British Phycological Journal, 27: 203-213. DOI: 10.1080/00071619200650201

SCARSBROOK, M., J. BARQUÍN \& D. GRAY. 2007. New Zealand coldwater springs and their biodiversity. Science for Conservation 278. Science \& Technical Publ., Department of Conservation, Wellington, New Zealand. 72 p.

STEVENS, L. E. \& V. J. MERETSKY (eds.). 2008. Arid land springs in North America: ecology and conservation. University of Arizona Press, Tucson, AZ. DOI: 10.14237/ebl.3. 2012.51

STEVENSON, R. J., A. PINOWSKA, A. ALBERTIN \& J. O. SICKMAN. 2007. Ecological condition of algae and nutrients in Florida springs: The Synthesis Report. Environmental Assessment Section, Florida Department of Environmental Protection.

THIENEMANN, A. 1922. Hydrobiologische Untersuchungen an Quellen. Archiv für Hydrobiologie, 14, 151-190. DOI: 10.1002/mmnd. 192619260102

THORP, J. H. \& A. P. COVICH. 2015. Chapter 2 - Overview of Inland Waters. In: Thorp, J. H. \& Rogers, C. (eds.), Thorp and Covich's Freshwater Invertebrates: Ecology and General Biology (Fourth Edition), 23-56. Academic Press. DOI: 10.1016/B978-0-12385026-3.00002-4

TRONSTAD, L.M. \& H. GRISCOM. 2012. Assessment of biological and physical relationships of spring and seep ecosystems across a gradient of human impacts. Report prepared for the USDI National Park Service, Devils Tower National Monument by the Wyoming Natural Diversity Database, University of Wyoming, Laramie, Wyoming. 
VAN DER KAMP, G. 1995. The hydrogeology of springs in relation to the biodiversity of spring fauna: A review. Journal of the Kansas Entomological Society, 68, 4-17.

WARINGER, J. \& W. GRAF. 2011. Atlas of Central European Trichoptera larvae. Erik Mauch Verlag, Dinkelscherben.

WEBB, D. W., M. J. WETZEL, L. R. PHILLIPPE, P. C. REED, \& T. C. YOUNG. 1995. Aquatic biodiversity in Illinois springs. Journal of the Kansas Entomological Society, 68 (2) suppl.: 93-107.

WEIGAND, E. 1998. Limnologisch-faunistiche Characterisierung von Karstquellen, Quell- bächen und unterirdischen Gewässern nach Choriotopen und biozönotischen Gewässerregionen Nationalpark o.ö. Kalkalpen, Österreich. Unpublished report. $173 \mathrm{pp}$.

WHITTAKER, R. H. (1960) Vegetation of the Siskiyou Mountains, Oregon and California. Ecological Monographs, 30: 279-338. DOI: $10.2307 / 1943563$

WILLIAMS, D. D. 1991. The springs as an interface between groundwater and lotic faunas and as a tool in assessing groundwater quality. Internationale Vereinigung für theoretische und angewandte Limnologie, 24: 1621-1624. DOI: $10.1080 / 03680770.1989 .11899034$

Con el patrocinio de:

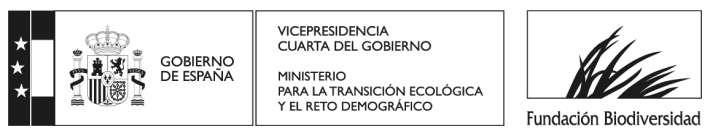

